\title{
NOISE LEVELS ALONG THE PALEMBANG-INDRALAYA HIGHWAY
}

\author{
Mona Lestari, ${ }^{1}$ Desheila Andarini ${ }^{1}$, Dwi Septiawati, ${ }^{2}$ Poppy Fujianti $^{1}$, Novrikasari ${ }^{1}$ \\ ${ }^{1}$ Occupational Safety and Health Department, Faculty of Public Health, Sriwijaya University \\ ${ }^{2}$ Environmental Health Department, Faculty of Public Health, Sriwijaya University
}

\begin{abstract}
Palembang - Indralaya highway is a cross-provincial road where motor vehicle activity is constant, causing noise and affecting settlements along the road. Constant exposure to the noise that exceeds quality standards $(55 \mathrm{~dB})$ stipulated in Environmental Ministerial Decree (KEP.48/MENLH/11/1996) can cause a variety of health problems, such as hearing loss and psychological disorders. This study is conducted to determine the noise level along the Palembang-Indralaya road. This study used an observational approach through direct observations and measurements using the Mini Sound Level Meter. The noise level is measured at two locations, i.e., on the curb and in houses located along the highway. Based on the observations and measurements, the overall highest noise level occurred in the daytime with the noise intensity of 102,40 $d B$. The highest intensity of noise inside and outside the house is 74 and $90 \mathrm{~dB}$, respectively. This high noise intensity is due to the high volume and activity of vehicles crossing the highway. The intensity of the noise received by the residents along the highway is above the quality standards. Therefore, solutions to handle the noise is to plant trees around the housing (barrier plants).
\end{abstract}

Keywords:Noise pollution, road traffic noise, barrier plants

\section{TINGKAT KEBISINGAN SEPANJANG JALAN RAYA PALEMBANG- INDRALAYA}

\begin{abstract}
ABSTRAK
Jalan raya Palembang - Indralaya merupakan jalan lintas provinsi dimana aktivitas kendaraan bermotor tidak pernah terhenti, sehingga menimbulkan kebisingan dan mempengaruhi pemukiman di sepanjang jalan. Pajanan kebisingan secara terus-menerus yang melebihi baku mutu (55 dB) yang ditetapkan dalam Keputusan Menteri Negara Lingkungan Hidup (KEP.48/MENLH/11/1996), dapat menyebabkan berbagai masalah kesehatan, seperti gangguan pendengaran dan gangguan psikologis. Oleh karena itu, penelitian ini menentukan tingkat kebisingan di sepanjang jalan Palembang-Indralaya. Penelitian ini menggunakan pendekatan observasional melalui pengamatan dan pengukuran langsung menggunakan Mini Sound Level Meter. Tingkat kebisingan diukur di dua lokasi, yaitu, di tepi jalan dan di rumah-rumah yang terletak di sepanjang jalan. Berdasarkan hasil pengamatan dan pengukuran menunjukkan bahwa secara keseluruhan tingkat kebisingan tertinggi terjadi pada siang hari, dengan intensitas kebisingan sebesar 102,40 dB. Intensitas kebisingan di dalam dan di luar rumah tertinggi secara berurutan adalah 74 dan $90 \mathrm{~dB}$. Hal ini disebabkan karena tingginya volume dan aktifitas kendaraan yang melintasi jalan raya Intensitas kebisingan yang diterima oleh masyarakat yang berada di sepanjang jalan berada diatas baku mutu yang telah ditentukan sehingga untuk meminimalisirnya dapat dengan melakukan penanganan terhadap media suara, seperti menanam pohon-pohon di sekitar perumahan (barrier tanaman).
\end{abstract}

Kata Kunci: Polusi Suara, Kebisingan Lalu Lintas, Barrier Tanaman

\footnotetext{
${ }^{1}$ Correspondece Address: Mona Lestari Street Palembang Prabumulih KM 32, Indralaya District Ogan Ilir, South Sumatera email: mona_lestari@fkm.unsri.ac.id
} 


\section{INTRODUCTION}

Nowadays, humans are increasingly exposed to pollution, whether we realize it or not. One of them is noise pollution. Human neglects noise pollution often, perhaps because its effects are not directly visible compared to other forms of pollution. However, it is as dangerous as other forms of pollution and can cause various health problems for humans. ${ }^{1}$ Unlike chemical pollution, noise hazards do not build up in the body or the environment but can cause shortterm and long-term adverse effects on human. ${ }^{2}$

Human settlement is one of the areas that are vulnerable to noise, and ironically, the community is unaware of this danger. Generally, the danger of noise is of particular concern in the industry, so there have been controlling measures done to overcome the risks that may arise through controlling sources of noise, mediators, and receivers. Meanwhile, the community of residential areas does not fully understand noise control measures.

Activity on the highway dominates the source of noise in residential areas. Noise disturbance caused by the highway depends on three main causes; the type, speed, and number of vehicles, the type of road surface structure, the characteristics of buildings, and the total population. ${ }^{3}$ In roads, vehicles contribute about $70 \%$ of noise. The engine, exhaust system of vehicles, aerodynamic friction, interaction between the vehicle and the road system, the interaction between vehicles and indiscriminate use of vehicle horns are all factors that produce vehicle noise. ${ }^{4,5,6}$ At low levels, the sounds generated by motor vehicle activity are tolerable, but at high levels, such sounds become a nuisance. ${ }^{7}$ These disturbances cause disorders that can significantly affect human health.

Prolonged exposure to noise levels over $85 \mathrm{~dB}$ may result in permanent or temporary loss of hearing. ${ }^{8}$ Noise can also cause psychological effects in the form of speech disorders, sleep disturbances, the impaired concentration, which results in decreased performance, communication disorders, and disorders of mental-emotional as well as disorders of the heart system and blood circulation. Mental emotional disorders can include disruption of work comfort, irritability, and short temper. Other health risks include coronary heart disease, ulcers, colitis, migraine, and increased blood pressure. ${ }^{2,9,10}$

Along highways, traffic is the main source of noise that disturbs most people. Although noise on highways has been a long-standing problem, however, no solution has been developed to address this issue. The highway generates various consistency of noise, depending on vehicle density on a thoroughfare. The longer the road, the higher the likelihood that the number of passing vehicles and traffic noise will increase. As a result, the health of residents who live along roadsides is adversely affected.

The noise level in Singapore increased along with the increase of population and road traffic, where there are 951.307 vehicles on Singapore highways at the end of June 2011, a $37 \%$ increase from 2000. ${ }^{1}$ Other data showed that the level of noise at Kuwait metropolis highway during peak hours and outside peak hours ranges from 66.7 to $94.8 \mathrm{dBA}$ and 64.9 to $89.1 \mathrm{dBA}$, respectively. ${ }^{11} \mathrm{In}$ Indonesia alone, there are several studies related to noise levels in settlements/housing, including those in Iswar and Malkhamah's research which shows that the noise level in a residential environment in Yogyakarta ranges from 71.89 dBA to $75.64 \mathrm{~dB},{ }^{12}$ Still in Yogyakarta, other studies conducted by Efendi and Malkhamah has noise levels ranged from $60.7 \mathrm{dBA}$ to 74.5 $\mathrm{dBA},{ }^{13}$ and the noise level in housing in DKI Jakarta ranged from $63.59 \mathrm{dBA}$ to 84.0 dBA. ${ }^{14}$ From these studies it is known that the noise level in settlements is very high, referring to the Decree of the Minister of 
Environment No.48 of 1996, where the noise level for settlements should not exceed 55 $\mathrm{dB} .{ }^{15}$

Adherence to this policy is necessary, especially along highways, such as the Palembang-Indralayahighway. This pathway is a cross-provincial road that serves as the only access to Sriwijaya University. The students, lecturers, and staff of the institution always travel through this road by way of public transport and private vehicles. Additionally, it is frequently traversed by heavy vehicles that carry products that are widely available in South Sumatra Province. The Palembang-Indralaya highway is always full of activity. This high activity has tremendously affected the settlements along the road. Furthermore, the majority of environment condition along PalembangIndralaya highway consists of wetlands and houses which was built right by the highway without any proper border such as fences or plant barriers.

Based on the issues, this study assumed that residents living along the PalembangIndralayahighway are susceptible to health problems given their exposure to motor vehicle activity. In addition to experiencing hearing loss, the residents may be suffering from other disorders, such as sleep disturbance, concentration and communication disorders, and emotional instability that influences blood pressure. To help minimize these problems, this research determined the noise levels along the Palembang-Indralaya highway through observation and instrument-aided measurement.

\section{METHOD}

This research was using an observational approach that features direct measurement using a Mini Sound Level Meter. Calibration to Sound Level Meter I always done before use. The research did noise measurement in two locations: on the edge of the highway and in the houses located along the highway. Measurement points in the highway were determined by observing congestion-prone areas, which also located near settlements, so ten measurement points along Palembang-Inderalaya highway were acquired with five measurement results for each point. Meanwhile, measurement points in local settlements were determined to be in the living rooms, kitchens, and bedrooms, by assuming that these rooms are where the locals spend most of their time within the 24 hours. Measurement areas along the road was assigned to a total of 10 measurement points, and there was 106 points measurement areas inside and outside the houses. The research conducted measurements in the morning, afternoon, evening, and night.

\section{RESULTS}

This research did noise level measurements at 10 points along the Palembang-Indralaya highway, with four measurements done every day during the study period indicating that they are all above the quality standards stipulated in the Decree of the Minister of Environment No.48 of 1996, presented in table 1 From the results of observations and measurements, the highest noise average happened in the daytime at $89,04 \mathrm{~dB}$, with the highest point recorded at $102,40 \mathrm{~dB}$. The lowest noise was recorded in the morning with the noise intensity at 66,70 $\mathrm{dB}$. However, the lowest noise average happened during the night time at 79,23 dB. The factor that influences the noise intensity along the Palembang Palembang-Indralaya highway is the high volume of vehicles passing the highway and the variety of the passing vehicles, be it heavy or private vehicles. 
Table 1. Noise Intensity along the Highway of Palembang-Indralaya (n=10)

\begin{tabular}{lcccc}
\hline $\begin{array}{c}\text { Waktu } \\
\text { Pengukuran }\end{array}$ & Mean & $\begin{array}{c}\text { Deviation } \\
\text { Standard }\end{array}$ & Min & Max \\
\hline Morning & 81,95 & 6,04 & 66,70 & 97,20 \\
Afternoon & 89,04 & 5,72 & 78,00 & 102,40 \\
Evening & 79,96 & 3,59 & 73,50 & 87,40 \\
Night & 79,23 & 3,64 & 72,60 & 85,40 \\
\hline
\end{tabular}

Table 2. presenting the results of the measurements conducted inside and outside the houses located along the highway. The average noise levels inside and outside the houses were $60.41 \mathrm{~dB}$ and $76.31 \mathrm{~dB}$, respectively. It can be concluded that the noise from the highway that exceeds the quality standards is exposing the public. Inside the houses, the lowest noise level is 45 $\mathrm{dB}$, and the highest is $74 \mathrm{~dB}$, while outside the houses, the lowest noise level is $51 \mathrm{~dB}$, and the highest is $90 \mathrm{~dB}$. Results of observation and interviews show that people who live along Palembang-Indralaya highway side reported experiencing health issue caused by noise, such as communication disruption, sleeping problem or insomnia and the decrease of hearing function.

Table 2. Statistic Measures of Noise Intensity in and Outside Resident Living Along the Highways of Palembang-Indralaya $(n=106)$

\begin{tabular}{lcc}
\hline \multicolumn{1}{c}{ Statistic Measure } & Inside (dB) & Outside (dB) \\
\hline Mean & 60,41 & 76,31 \\
Deviation Standard & 8,166 & 7,534 \\
Minimum & 45 & 51 \\
Maximum & 74 & 90 \\
\hline
\end{tabular}

\section{DISCUSSION}

The highway is the main source of noise in the settlement areas. ${ }^{16}$ Traffic noise is very dependent on several parameters, such as the traffic volume, the traffic flow typology, the vehicle typology, the road and pavement features, the speed, and interaction between tires and the road. ${ }^{17}$ The PalembangIndralayahighway is a cross-provincial thoroughfare where the volume of vehicles is constantly increasing. The types of vehicles that travel over this road range from private vehicles and public transportation to heavy vehicles. Because it is the only access road to the University of Sriwijaya, the number of university students, employees, and lecturers increase vehicular volume on weekdays. This increased volume causes noise levels along the highway to exceed $55 \mathrm{~dB}$. With the increasing of motorized vehicle use, the noise level on the edges of highways in some major cities in Indonesia generally approaching 70 to $80 \mathrm{dBA}^{18}$

The public health sciences defines noise as an unexpected and unpleasant, disturbing sound or a sound that is desirable but may potentially cause health problems. The World Health Organization categorized noise as a type of pollutant. Noise sources include motor vehicle activity. As the number of motorcycles increase, highway noise levels in some major cities in Indonesia generally approach $70-80 \mathrm{~dB}(\mathrm{~A}){ }^{18}$ Noise due to highway activity is referred through several terms, such as environmental noise, road traffic noise, traffic noise, and transportation noise. Human and transportation activities, such as those occurring on highways, railways, and airports usually cause environmental noise which pertains to 
undesirable noise caused by a small source (except industrial sites) $^{19}$

The type, speed, and number of vehicles greatly influencing noise level on thehighway. The type of road surface structure and building characteristics also influence the level of noise exposure in the community. ${ }^{3}$ The results of this study indicate that the noise level is highest during the daytime, where it is the peak rush hour due tothe increase of vehicle volume, both private vehicles, public transportation, and heavy vehicles.

Other studies mentioned that engine speed could alo generate noise level. AlQdah investigated noise pollution from the type of car that is often used by Arabs. The research shows that it recorded the noise levels produced by variable engine speed ranged from750 to $4000 \mathrm{rpm}$. The sound level found to be $59.45 \mathrm{dBA}$ when the vehicle in motion at normal speed. When the vehicle at idle speed $750 \mathrm{rpm}$ the maximum noise level measured at the back exhaust $50.4 \mathrm{dBA}$ where the minimum level recorded at the right side $40.8 \mathrm{dBA}^{21}$

Other studies conducted by Khasanah, et al. On one of the Yogyakarta highways shows that the equivalent noise level in the morning measurement ranges from $68.5 \mathrm{dBA}$ to $72.4 \mathrm{dBA}$, during the day it ranges from 69.1dBA to $71.3 \mathrm{dBA}$, and in the afternoon it ranges from $67.9 \mathrm{dBA}$ up to $70.6 \mathrm{dBA}^{21}$ These results indicate the noise level exceeds the standard due to the high traffic flow along the road. ${ }^{21}$

Dratva et al.'s study in Switzerland revealed the actual effects of the noise level generated by the vehicular current on disturbances in the surrounding community. Constant exposure to noise poses adverse effects, such as psychological disorders, including difficulty concentrating and sleeping, irritability, and stress; the other negative effects of noise are dizziness, fatigue, decreased labor, hearing loss, muscle tension, blood vessel contraction, increased blood pressure and heart rate rhythm, and increased adrenaline production. ${ }^{22}$ Noise is also unfavorable for the cardiovascular system. ${ }^{23}$

Residents who live along the edge of the Palembang-Indralayahighway occupy a noisy risk area, as evaluated based on related criteria. Such locations are those that span an area of $0-10 \mathrm{~m}$ from the edge of pavement, experience a noise level of more than 75 $\mathrm{dB}(\mathrm{A})$ (Leq), and experience a noise intensity of $75-90 \mathrm{~dB}(\mathrm{~A})$ for a maximum of 10 hours per day in the daytime and less than 4 hours per day at night. ${ }^{24}$

The noise that occurs in residential areas requires serious handling given human health effects that ultimately influence the quality of life in these communities. ${ }^{14}$ Setiawan explained that noise could be addressed by focusing on three factors, namely, the sound source, the voice media, and the receiver. Among these factors, addressing the sound media provides a solution to noise problems; an example solution is to plant trees (barrier plants) around houses. ${ }^{14}$ Mak and Leung has shown that there is a decrease of noise level after barrier installation, from $17 \mathrm{~dB}$ Ato $0,2 \mathrm{dBA} .{ }^{25}$

\section{CONCLUSION}

The highest average noise level occurred during the daytime at $89,04 \mathrm{~dB}$, and the lowest average occurred during the night at $79,23 \mathrm{~dB}$. From the result of the overall measurement, it is known that the highest noise level occurred during the day time with a noise intensity of $102,40 \mathrm{~dB}$. Therefore, it is necessary to take control measures to protect people exposed to noise along the highway from the risk of noise, by handling sound media, like planting trees around housing (plant barriers). 


\section{REFERENCES}

1. Bhanap I. An Analysis of Highway Noise at Residential Estates in Close Proximity to Expressways in Singapore. Noise Heal. 2013;15(64):183-9.

2. Ibitoye ZA, Aweda AM, Ofojebe PC. Assessment of Noise Level Distributions in Lagos Metropolis and The Potential for Adverse Health Effects. J Environ Health. 2017;79(10):E1-5.

3. Avsar Y, Gonullu MT. Determination of Safe Distance between Roadway and School Buildings to Get Acceptable School Outdoor Noise Level by Using Noise Barriers. Build Environ. 2005 Sep;40(9):1255-60.

4. Björk J, Ardö J, Stroh E, Lövkvist H, Östergren PO, Albin M. Road Traffic Noise in Southern Sweden and Its Relationto Annoyance, Disturbance of Daily Activities and Health. Scand J Work Environ Heal. 2006;32(5):392 401.

5. Chauhan A, Pawar M, Kumar D, Kumar N, Kumar R. Assessment of Noise Level Status in Different Areas of Moradabad City. Rep Opin. 2010;2(5):88-90.

6. Pathak V, Tripathi BD, Mishra V kumar. Evaluation of Traffic Noise Pollution and Attitudes of Exposed Individuals in Working Place. Atmos Environ. 2008;42(16):3892-8.

7. Djalante S. Analisis Tingkat Kebisingan di Jalan Raya yang Menggunakan Alat Pemberi Isyarat Lalu Lintas (APIL) (Studi Kasus: Simpang Ade Swalayan). J Smartek. 2010;8(4):280-300.

8. L L, Doelle. Akustik Lingkungan. Jakarta: Penerbit Erlangga; 1993.

9. Harianto E, Pratomo H. Pajanan Kebisingan dan Hipertensi di Kalangan Pekerja Pelabuhan. J Kesehat Masy Nas. 2013;8(5):215-20.

10. Ikron, Djaja IM, Wulandari RA. Pengaruh Kebisingan Lalulintas Jalan terhadap Gangguan Kesehatan Psikologis Anak SDN Cipinang Muara Kecamatan Jatinegara, Kota Jakarta Timur, Propinsi DKI Jakarta, 2005. Makara Kesehat. 2007;11(1):32-7.

11. Al-Mutairi NZ, Al-Attar MA, Al-Rukaibi FS. Traffic-Generated Noise Pollution: Exposure of Road Users and Populations in Metropolitan Kuwait. Environ Monit Assess. 2011 Dec;183(1-4):65-75.

12. Iswar, Malkhamah S. Pemodelan Tingkat Kebisingan Lalu Lintas di Lingkungan Perumahan (Studi Kasus Perumahan Dosen UGM-Sekip Yogyakarta). Forum Tek. 2005;29(2):91-7.

13. Efendi A, Malkhamah S. Persepsi Penghuni terhadap Tingkat Kebisingan Lalu Lintas dan Evaluasi Baku Mutu di Perumahan: Penelitian Terkoordinassi Studi Kasus di Yogyakarta. Universitas Gadjah Mada; 2003.

14. Setiawan MF. Tingkat Kebisingan Pada Perumahan Di Perkotaan. J Tek Sipil dan Perenc. 2010;12(2):191-201.

15. Keputusan Menteri Negara Lingkungan Hidup Nomor: KEP48/MENLH/11/1996. KEP48/MENLH/11/1996 Indonesia; 1996.

16. Covaciu D, Florea D, Timar J. Estimation of The Noise Level Produced by Road Traffic in Roundabouts. Appl Acoust. 2015;98:43-51.

17. Guarnaccia C. Advanced Tools for Traffic Noise Modelling and Prediction. WSEAS Trans Syst. 2013;12(2):121-30.

18. Mediastika CE. Akustika Bangunan. Jakarta: Penerbit Erlangga; 2018.

19. WHO. Burden of Disease from Environmental Noise: Quantification of Healthy Life Years Lost in Europe. Theakston F, editor. Denmark: World Health Organization; 2011. 126 p.

20. AlQdah KS. Experimental Investigation of Noise Pollution Level Emerged from The Most Common Use Car in Saudi Arabia. In: Energy Procedia. Elsevier Ltd; 2013. p. 939-47.

21. Khasanah LH. Hubungan Tingkat Kebisingan Lalu Lintas dan Volume Kendaraan terhadap Kenyamanan Layanan Fasilitas Umum di Sepanjang Jalan Cik Di Tiro Kota Yogyakarta. Geo Educ. 2017;2(8):1005-17.

22. Dratva J, Phuleria HC, Foraster M, Gaspoz JM, Keidel D, Künzli N, et al. Transportation Noise and Blood Pressure in A Population-Based Sample of Adults. Environ Health Perspect. 2012;120(1):50-5.

23. Wu X, Yang D, Fan W, Fan C, Wu G. 
Cardiovascular Risk Factor in NoiseExposed Workers in China: Small Area Study. Noise Heal. 2017;19(91):245-53.

24. Departemen Permukiman dan Prasarana Wilayah. Pedoman Prediksi Kebisingan Akibat Lalu Lintas. Departemen
Permukiman dan Prasarana Wilayah; 2004.

25. Mak CM, Leung WS. Traffic Noise Measurement and Prediction of The Barrier Effect on Traffic Noise at Different Building Levels. Vol. 12. 2013. 